\title{
子宮鏡下手術により子宮を温存し得た胎盤ポリープの5症例の検討
}

大分大学産科婦人科教室

西田正和、河野康志、弓削彰利、奈須家栄、松本治伸、楢原久司

\section{Five Cases of a Placental Polyp Successfully Treated by Hysteroscopic Surgery}

\author{
Masakazu Nishida, Yasushi Kawano, Akitoshi Yuge, Kaei Nasu, \\ Harunobu Matsumoto, and Hisashi Narahara \\ Department of Obstetrics and Gynecology, Oita Medical University, Oita, Japan
}

\begin{abstract}
Background: Placental polyps can causes massive postpartum hemorrhage. The traditional treatment for a placental polyp is a hysterectomy. However, for patients desirous of a subsequent pregnancy, an alternative treatment option is uterine artery embolization (UAE) and hysteroscopic surgery.

Patients: Case 1 is a 35-year-old Japanese gravida 0, para 0 who had an unremarkable medical and family history. She delivered at another hospital, and was transferred to our hospital because of massive hemorrhage secondary to residual placenta. The residual placenta was completely excised at our hospital. One month later, she was again transferred to our hospital due to recurrent hemorrhage; a placental polyp was imaged by an ultrasound examination. She was strongly desirous of uterine preservation; therefore, she was successfully treated by UAE and hysteroscopic resection of the placental polyp.

Cases 2 through 5 had similar clinical findings as that of Case 1 and were successfully treated by UAE and/or hysteroscopic surgery.

Conclusions: UAE and hysteroscopic surgery is effective for the treatment of a placental polyp. Conversely, some cases of placental polyps spontaneously resolve without any treatment. Therefore, we must recognize that there are many cases of placental polyps that can be treated with uterine preservation, if the general patient status is stable.
\end{abstract}

Key words: hysteroscopic surgery, placental polyp, uterine preservation

\section{はじめに}

胎盤ポリープは、産裖期出血の原因となる疾患 であるが、安易な子宮内掻爬は大量出血や子宮穿 孔を引き起こし、ひいては子宮摘出を余儀なくさ れる。

胎盤ポリープに対する最も確実な治療法は子宮 摘出だが、子宮温存を強く希望する患者には、子 宮動脈塞栓術や子宮鏡下手術などの保存的治療が 選択され、多くの成功例の報告もみられる。

今回、子宮温存を希望する胎盤ポリープに対し、
子宮鏡下手術で腫瘤を切除し、子宮を温存し得た 当施設の 5 症例について報告する。

\section{症例}

症例 1

35歳、経妊 1 、経産 1 。既往歴、家族歴に特記事 項なし。妊娠成立後、A産婦人科で妊娠管理を受 けていた。里帰り分娩のため妊娠32週以降、B産 婦人科で妊娠管理を受けていた。妊娠38週3日、 同院での経腟分娩後、1,000ml程度の出血があり、 胎盤遺残を疑われて当科へ搬送された。当院では 
残存胎盤を剥離し、頸管部に認めた裂傷を縫合し 止血した。処置後は、経腹超音波断層法上、胎盤 の遺残は認めず (図 1 )、産裖 3 日目に紹介元の 医院へ転院した。その後、産裖32日目に大量出血 があり、再度当科を紹介された。来院時、多量の 出血および血塊を認めへモグロビン值は $7.2 \mathrm{~g} / \mathrm{dl}$ 、 ヘマトクリット值は $21 \%$ と高度の貧血を認めた。 経腟超音波断層法では、子宮内に血流を伴った径 $3 \mathrm{~cm}$ 程度の腫瘤を認め (図 2 )、臨床的経過から 胎盤ポリープを疑った。バイタルサインは安定し ていたものの、出血も持続しており、同日、血管 造影下に両側の子宮動脈をスポンゼルで塞栓し (図 3、4)、その翌日、子宮鏡下に腫瘍摘出手術 を施行した。摘出腫㢚は、結合組織様で肉眼的に 絨毛成分は認められなかった（図 5 )。組織学的 には、「絨毛の半分以上は変性・壞死しており、 一部に小石灰化を混じている。脱落膜には血管拡 張と変性がみられ、胎盤ポリープとして矛盾しな

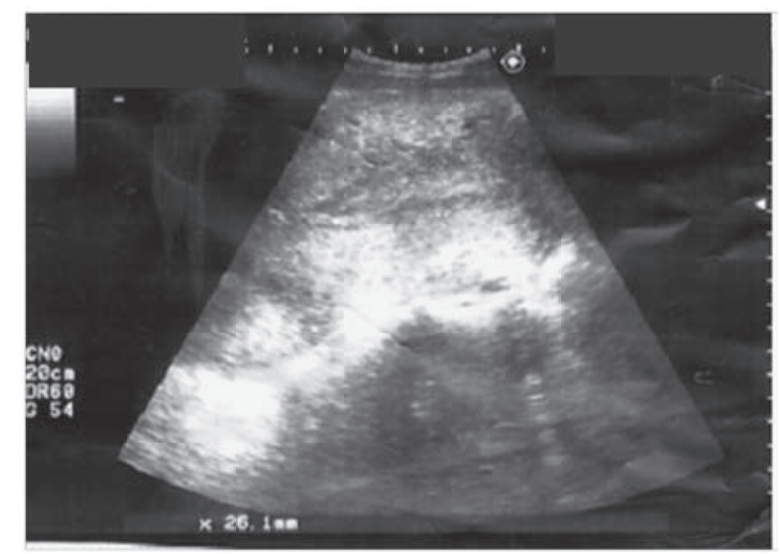

図 1 分娩後の超音波断層法写真だが、子宮内に明らかな腫瘤様の 構造物は認めない。

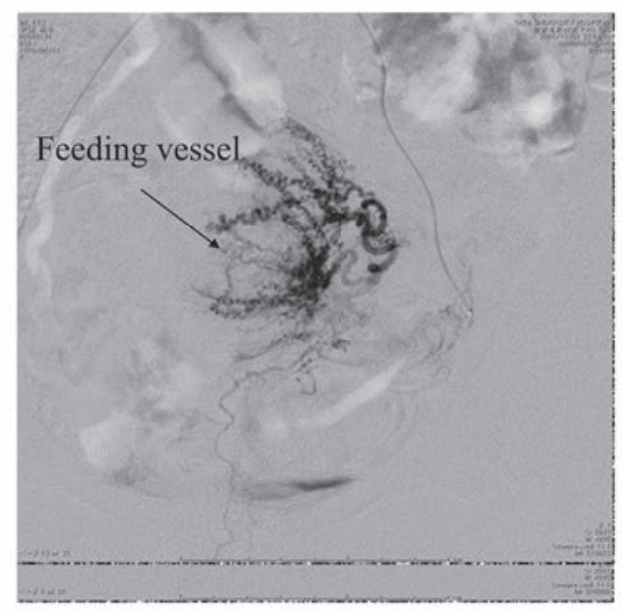

図 3-A 子宮動脈塞栓前
い」という所見であった。術後の経過は良好で、 4日目に退院し、以後外来で子宮腔内の癒着防止 のためKaufmann療法を行った。

残り 4 症例は、詳細を表 1 にまとめる。症例 2 は中期中絶後、症例 3 は初期中絶後の症例である。 いずれも、中絶後子宮内にはっきりとした胎児成 分はないことが確認されており、その後時間が経 過し、出血のため受診をした際、子宮内に腫瘤が 認められ、胎盤ポリープと診断し治療した。

症例 $4 、 5$ は症例 1 と同様に満期産後の症例で、 胎盤ポリープの診断後治療された。症例 $3 、 4$ に ついては、画像上血流にそしく、超音波断層法検 査のパワードップラーモードで測定した血管径が $2 \mathrm{~mm}$ 以下であり、腫瘤径も小さかったため、子 宮鏡下摘出術のみ行い子宮の温存が可能であっ た。

図 6 には当院で行っている胎盤ポリープ治療の ストラテジーを示している。

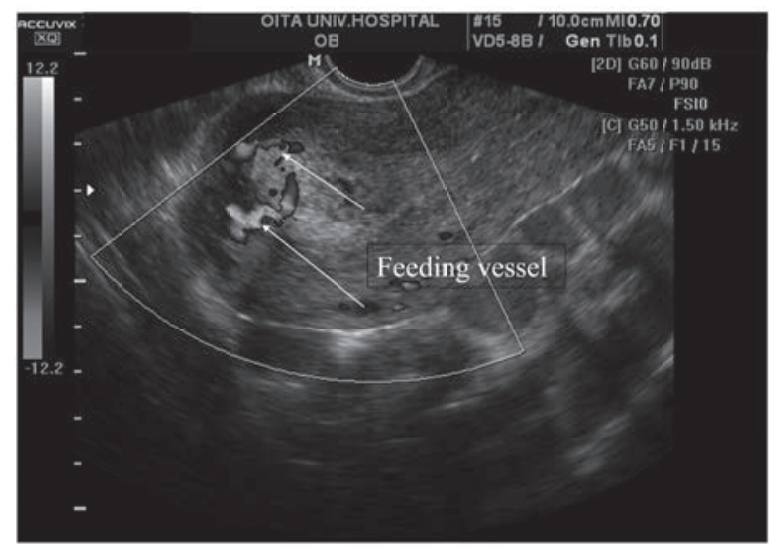

図2 前回図 1 では認められなかった血流を伴う $3 \mathrm{~cm}$ の腫瘤が存在 し、胎盤ポリープが疑われた。

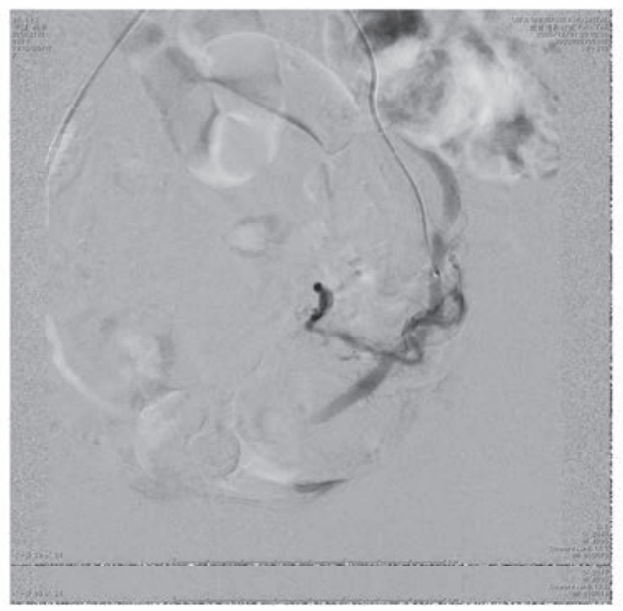

図 3-B 子宮動脈塞栓後

図3ーA 胎盤ポリープを養う豊富な血流が認められる。

図3ーB 血管造影下に血管を塞栓し、胎盤ポリープヘの血流を遮断。 


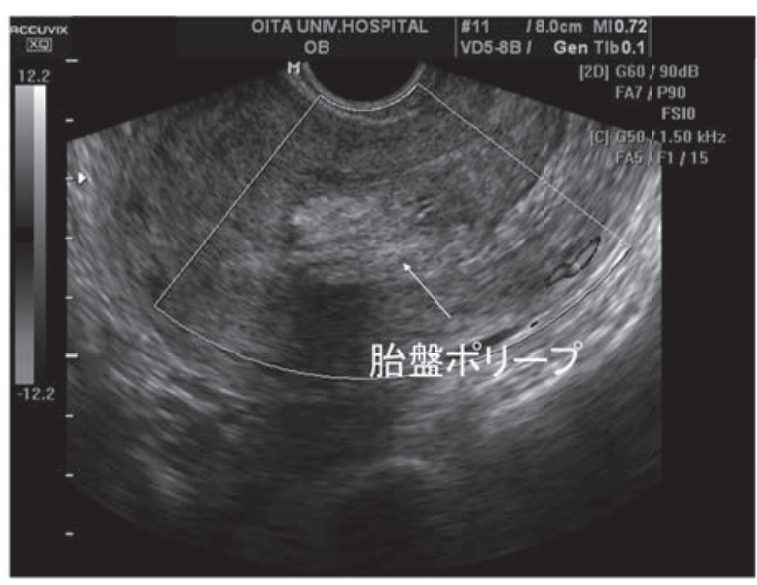

図４血管塞栓後は、超音波断層法検査上も血流は認めない。

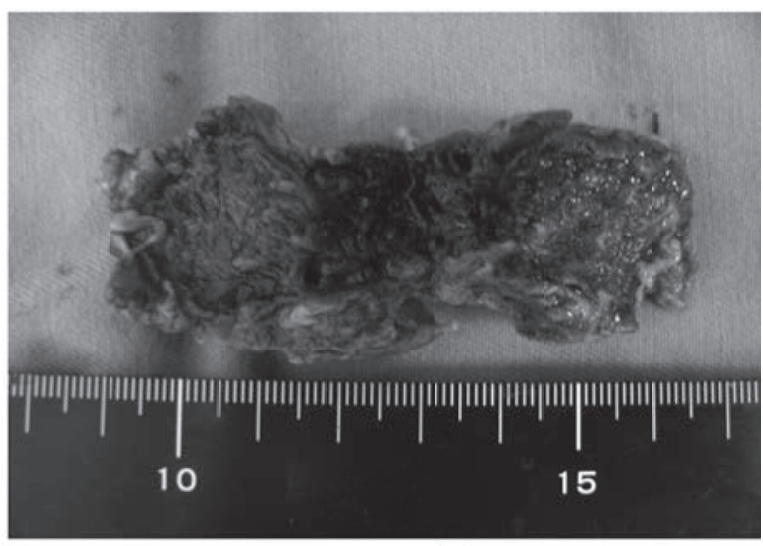

肉眼所見

図 5 摘出標本所見。結合組織様の腫瘤で、緁毛などの胎盤成分は 認めない。

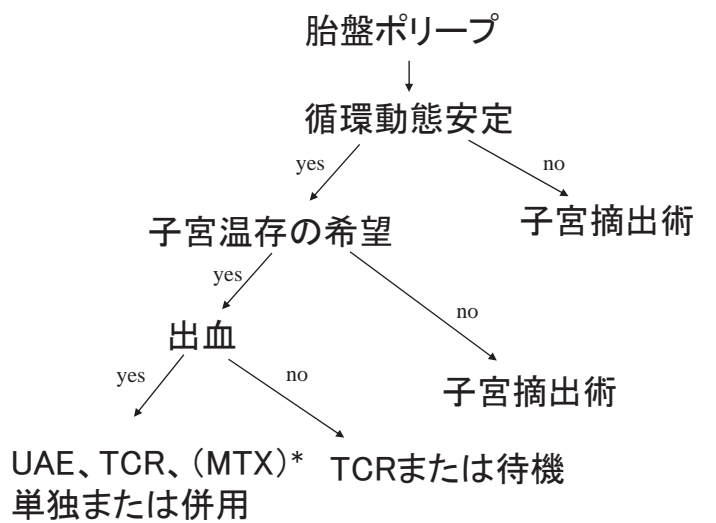

*ただし、本邦では、MTXは保険適応となって いないため、実際に使用することは難しい。

図 6 当院における胎盤ポリープ治療のストラテジーを示す。子宮 温存の希望のある症例では、全身状態が落ち着いていれば、 UAE、TCR等を用いて可能な限り子宮の温存を図る。

\section{考察}

胎盤ポリープはまれな疾患で、原因としては、 遺残胎盤が変性し、フィブリン沈着や硝子化など の器質的変化によりポリープを形成するといわれ ている。発症時期に関しては、分娩数日から数週 間後が大部分であるが、無症状のまま経過し、数 年経過して発見されるケースもある1)。一方、類 似疾患として、遺残胎盤があり、胎盤ポリープと 一括して扱われることも多く、両者の区別は必要 ないという意見も存在する ${ }^{1)}$ 。実際には、遺残胎 盤は、分婏直後より、子宮内に胎盤の遺残が確認 され、血中hCGも高值であるのに対し、胎盤ポリ

表 1 当院での 5 症例のまとめ

\begin{tabular}{|c|c|c|c|c|c|c|c|c|}
\hline 症例 & 年齢 & 経妊 & 経産 & $\begin{array}{l}\text { 分婏週数 } \\
\text { 分婏樣式 }\end{array}$ & 最大腫瘤径 & $\begin{array}{c}\text { hCG* } \\
(\mathrm{mlU} / \mathrm{ml})\end{array}$ & $\begin{array}{c}\text { 診断まて } \\
\text { の期間 }\end{array}$ & 治療 \\
\hline 1 & 35 & 1 & 1 & $\begin{array}{c}\text { 38週3日 } \\
\text { 経腟分婏 }\end{array}$ & $30 \mathrm{~mm}$ & $<1.0$ & 約1ケ月 & $\mathrm{UAE}+\mathrm{TCR}$ \\
\hline 2 & 30 & 3 & 2 & $\begin{array}{l}\text { 16週6日 } \\
\text { 中期中絶 }\end{array}$ & $15 \mathrm{~mm}$ & $<1.0$ & 約2个月 & $\mathrm{UAE}+\mathrm{TCR}$ \\
\hline 3 & 18 & 0 & 0 & $\begin{array}{c}\text { 7週1日 } \\
\text { 初期中絶 }\end{array}$ & $20 \mathrm{~mm}$ & 233 & 約1ケ月 & TCR \\
\hline 4 & 32 & 1 & 1 & $\begin{array}{l}\text { 38週5日 } \\
\text { 帝王切開 }\end{array}$ & $14 \mathrm{~mm}$ & $<1.0$ & 約2个月 & TCR \\
\hline 5 & 31 & 2 & 2 & $\begin{array}{l}\text { 40週2日 } \\
\text { 経腟分婏 }\end{array}$ & $50 \mathrm{~mm}$ & 155 & 約1ケ月 & $\mathrm{UAE}+\mathrm{TCR}$ \\
\hline
\end{tabular}

UAE: Uterine Artery Embolization

TCR: Trans Cervical Resection * hCGは胎盤ポリープ診断時の值 
ープは、分娩後数週間から数か月経過して子宮内 に腫瘤が確認され、血中hCG值も低值であること で区別されることが多い2)。本症例では、いずれ も分娩後は子宮内の腫瘤ははっきりせず、1ヶ月 から2ヶ月後に子宮内に腫瘤形成が認められたた め胎盤ポリープと診断し、治療した。

胎盤ポリープの診断には、画像診断が不可欠で、 超音波断層法では、子宮腔内の不均一な高輝度工 コーを示すポリープ状腫瘤と混在した液体の貯留 が特徵的であり、豊富な血流を持つことが多い。 MRIでは、T1、T2強調画像でともに高信号を示 す。また、血流が豊富なため強い造影効果がある ことも特徴とされる ${ }^{2)}$ 。画像診断で、絨毛性疾患 との鑑別が困難となることがあるが、絨毛性疾患 では、血中hCG值が高く、胎盤ポリープでは血中 hCG值が低いことが鑑別点の一つにあがる。ただ し、最終診断は組織学的診断による。

当院の胎盤ポリープの治療には図6に示すよう なストラテジーで治療していく。循環動態を保て ないような多量の出血がある場合には、妊孕性温 存の希望の有無にかかわらず、子宮摘出が考慮さ れる。出血のコントロールがつき、保存的治療が 選択される場合には次のような方法が挙げられ る。

(1) 子宮動脈塞栓 (UAE)、子宮鏡下摘出術 (TCR) 一般に、胎盤ポリープは血流が豊富でTCRの みでは止血が不十分なこともある。胎盤ポリープ を含んだ産裖期出血に対し、その治療に時間的余 裕がある場合には、UAEは止血の手段として非

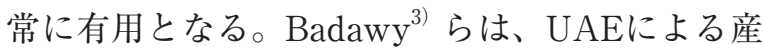
裖期出血の止血成功率は約 $95 \%$ であったと報告し ている。また、Salomonら ${ }^{5)}$ は産裖期出血の17症 例全例にUAEを行い、全例で子宮を温存するこ とができ、うち 5 例で妊娠、出産したと報告して いる。

血流が豊富な胎盤ポリープの場合は、前述した UAEにより、血流を遮断した上でTCRを用いる とより安全である。Hirakiら ${ }^{6)}$ の報告では、8例 の胎盤ポリープに対し、 5 例の症例はTCRのみ で保存的に加療が可能であったと報告している(1 例がD\&Cのみで加療、 1 例がTCRから開腹手術 に変更、 1 例が子宮動脈をクランプし、 TCR施 行)。また、貞森ら ${ }^{7}$ は 9 例の胎盤ポリープに対 しTCRを行い（1例のみTCR前にMTX投与）、 全例で子宮を温存できたと報告している。このよ うに、UAEやMTXの補助下に行われることもあ るが、TCRは子宮温存を希望する胎盤ポリープ
の症例に非常に有用であると考えられる。

(2) メトトレキサート（MTX）投与

胎盤ポリープ組織の壊死を期待し、メトトレキ サートの全身投与を行い、そのまま保存的にみる 方法、または、投与後にTCRを施行する方法が ある。ただし、本邦では、MTXは保険適応とな っていないため、実際に使用することは難しい。

(3) 待機療法

出血のない、もしくは少ないケースでは、時間 経過により、腫瘤が縮小・消失することがあるた め、経過をみることもある ${ }^{4)}$ 。

今回検討した 5 症例では、当初中等量〜大量 の性器出血を認めたが、子宮温存の希望が強く、 TCR単独またはUAEを併用した治療を行った。 TCRのみで子宮温存が可能であった報告もみら れるが、今回の症例は、胎盤ポリープの大きさと それを栄養している血管径の太さでUAEを行う か否かの判断を行った。厳密な基準を設けていな いが、腫瘍径が概ね $2 \mathrm{~cm}$ 以下、血管径が $1 \sim 2$ $\mathrm{mm}$ の場合はTCRのみで治療を行った。その結果、 すべての症例で子宮を温存することが可能であっ た。過去の報告通り、全身状態が許せば、保存的 手術も十分可能であるため、十分なインフォーム ドコンセントの下、治療していくことが必要だと 思われる。

\section{まとめ}

胎盤ポリープに対する治療は、その時の全身状 態が優先される。安易に盲目的な子宮内掻爬を行 うことは非常に危険だが、循環動態に影響するよ うな出血がない症例においてはUAEやMTX投与 を併用したTCRにより子宮温存が可能なケース が多く、治療法の決定には十分なインフォームド コンセントが必要である。

\section{参考文献}

1 ）奥田 靖彦、他：【知って扰きたい重症産裖合併症】胎 盤遺残、胎盤ポリープ、産科と婦人科、2012；79： 1102-1108.

2) 秋山直子、他：胎盤ポリープに対して動脈塞栓術を 施行した2例、臨床放射線、2012；57：820-824.

3 ) Badawy SZ, et al. Uterine artery embolization: the role in obstetrics and gynecology, Clin Imaging, $2001 ; 25: 288-295$.

4）古澤嘉明、他：胎盤遺残、胎盤ポリープの取り扱い、 産科と婦人科、2008；75:898-904

5 ) Salomon LJ, et al. Fertility and pregnancy outcome 
following pelvic arterial embolization for severe post-partum haemorrhage. A cohort study. Hum Reprod, $2003 ; 18: 849-852$.

6 ) Hiraki K, et al. Uterine preservation surgery for placental polyp. J Obstet Gynaecol Res, 2014 ; 40 : 89-95.

7 ）貞森 理子、他：子宮鏡下手術で治療し得た胎盤ポリ ープ9例の検討、日産婦内視鏡学会誌 $2007 ; 22: 371$ 374 